\title{
THE VIRTUAL SHOPPING EXPERIENCE: USING VIRTUAL PRESENCE TO MOTIVATE ONLINE SHOPPING
}

\author{
Carolyn Ye-Phern Chin, South-East Water, Melbourne, Australia \\ Email: carolyn.chin@sewl.com.au \\ Paula M.C. Swatman, University of South Australia, Adelaide, Australia \\ Email: paula.swatman@unisa.edu.au
}

\begin{abstract}
Online shopping has thus far tended to be a niche business - highly successful in selling digital products such as shares, software and, increasingly, music and films, it has been less successful in persuading the purchasers of 'traditional' goods such as cars, clothes, toiletries, or household appliances to forsake their physical retailers and move into cyberspace.

In this wide-ranging review paper we investigate the issue of the virtual experience endeavouring to understand what is needed for a successful 'shopping experience' online and what the possible obstacles or pitfalls along the way might be. We initially introduce the concepts of virtual presence (the sense of 'being there') and virtual reality, discussing the possible roles both can play in providing a solution to the problem of effective online shopping. We then consider the Experience Economy, a concept which encapsulates many of the issues related to the problem of online shopping and which suggests ways in which online retailers can enhance the effectiveness of their sites by means of a virtual 'experience'.

Having set the scene for online shopping, we discuss eTailing today in terms of direct product experience and the opportunities which cyber-shopping offers to replicate this process. Finally, we identify some of the possibilities and problems of online shopping today, illustrating the current status of virtual presence in retailing with two micro-cases of success and failure.
\end{abstract}

Keywords: Online shopping, innovative value added services, presence, virtual presence, Virtual Reality, Experience Economy.

\section{INTRODUCTION}

Although the Internet has provided consumers with global access to an unlimited array of goods available for purchase, overall purchasing levels and, in particular, the online purchase of goods which normally require physical presence, such as clothing, footware, cars and other, similar 'tactile' products is a hurdle to the uptake of truly widespread online shopping. Hou and Rego (2002) note that the decision to shop online depends to a large extent on the shopping experience the consumer is willing to accept and point out that online shopping still lacks social interactivity.

As far back as 1972, Tauber extended McClelland's Primary Social Motives (1961) into a more specialised set of social motives driving consumer purchasing behaviour: (i) social experience; (ii) communication with others; (iii) peer group attraction; (iv) status and authority; and (v) the pleasure of bargaining. Indeed, the social aspects of shopping are a major attraction for many people. A qualitative study of shopper motivation in the UK (Dennis et al., 2002) found that the social dimension was a very important factor for many of the study's participants. As one respondent noted: "Shopping has become going out, meeting friends, Starbucks, Pret à Manger [a British restaurant chain]”. Online shopping fits Westbrook and Black's (1985) three shopping motivation concepts - diversion from routine activities, sensory stimulation and learning about new trends - to a large extent, but Tauber's five fundamental motives are more closely linked to human social contact and 
consequently harder to match. If it is to be truly successful and fulfil its promise, online shopping must find some way to fulfil the human needs currently met by face-to-face shopping activities.

This review paper discusses the ways in which "virtual presence" might offer a partial solution to this problem, by enabling online shoppers to interact with and modify (or enhance) their shopping experience. We begin by introducing the literature relating to virtual presence and virtual reality, discussing the possible roles of these concepts in providing a solution to the problem of effective online shopping. We continue our discussion by considering the ways in which virtual presence affects and is affected by the online shopping 'experience' - which must provide something as satisfying as today's physical shopping experience - and extend this discussion by considering the direct shopping experience, in which physical touch and test must now be replaced by its virtual equivalent.

We next consider online retailing today, discussing motivations for buying online. We revisit the issue of the online experience, using two micro-cases of a high-profile failure and a less high-profile success to show what is possible in etailing today and, finally, we discuss the pros and cons of VR-enhanced cyber-shopping and the likelihood of its success in today's environment.

\section{PRESENCE, VIRTUAL PRESENCE AND VIRTUAL REALITY}

Virtual reality and other emerging technologies are designed to give the user a kind of mediated experience which creates a strong sense of presence (Lombard \& Ditton, 1997). IJsselsteijn (2002, p.245) points out that in one sense all reality is virtual, being constructed through the observer's cognitive and sensory abilities: "reality is not 'out there', it is what we take to be 'out there' ... one can produce illusions which the brain will be unable to discriminate from physical reality".

Steuer (1992) defined virtual reality as a particular type of experience which involves the sense of "presence" - or the sense of being in a particular place. An enhanced sense of presence is central to the use of virtual reality in a commercial environment, leading to enhanced usefulness and profitability. Furthermore, a better understanding of what presence is can save valuable time and money - and improve the end-product in the design of current and new media technologies (Lombard \& Ditton 1997).

But what might be needed to create an effective sense of presence? Table 1 summarises the work of five groups of researchers who have investigated the factors which make up presence: 


\begin{tabular}{|l|l|l|l|}
\hline $\begin{array}{l}\text { Kim \& Biocca, } \\
1997\end{array}$ & Schubert et al., 1999 & Lessiter et al., 2000 & $\begin{array}{l}\text { Enlund, 2000; } \\
\text { Knudsen, 2002 }\end{array}$ \\
\hline $\begin{array}{l}\text { Arrival } \text { - the sense } \\
\text { of "being there" in } \\
\text { the virtual } \\
\text { environment }\end{array}$ & $\begin{array}{l}\text { Spatial presence- } \\
\text { the sense of "being } \\
\text { there" in the virtual } \\
\text { environment }\end{array}$ & $\begin{array}{l}\text { Physical space - the } \\
\text { sense of "being there" } \\
\text { in the virtual } \\
\text { environment }\end{array}$ & $\begin{array}{l}\text { Sensory environment } \\
\text { - vividness, } \\
\text { company of others }\end{array}$ \\
\hline $\begin{array}{l}\text { Involvement- } \\
\text { concentration only } \\
\text { on the virtual space } \\
\text { sense of "not } \\
\text { being" in the } \\
\text { physical } \\
\text { environment }\end{array}$ & $\begin{array}{l}\text { Rengagement - } \\
\text { intensity of the } \\
\text { experience } \\
\text { believability of the } \\
\text { virtual environment }\end{array}$ & $\begin{array}{l}\text { Naturalness - } \\
\text { believability of the } \\
\text { virtual environment }\end{array}$ & $\begin{array}{l}\text { Individual pre- } \\
\text { conditions - } \\
\text { suspension of } \\
\text { disbelief }\end{array}$ \\
\hline & $\begin{array}{l}\text { Content } \\
\text { characteristics - } \\
\text { believability of the } \\
\text { virtual environment }\end{array}$ \\
\hline
\end{tabular}

Table 1. A comparison of "sense of presence" factor analysis studies

All five groups of authors found that presence is likely to be related not only to the user's sense of a physical, spatial environment, but also to his/her personal evaluation of the appeal and believability of both the environment and its content (in other words, the entire experience). Kim \& Biocca (1997), importantly, concluded that simply feeling present in the virtual environment was not sufficient to create a strong memory of the experience only when users no longer felt present in their physical environment was there an effect on memory (and hence persuasion).

Unlike traditional in-store retailing, where shopping information is conveyed to consumers through several channels, including: the store environment itself, product trial, product offering or service (Schiffman et al., 1977), B2C eCommerce relies solely on the web interface for communication and for managing customer relationships (Jiang \& Benbasat, 2002; Benbasat \& DeSanctis, 2000). Two issues are particularly relevant to relationship management in an online shopping environment:

- $\quad$ para-social presence (Jiang \& Benbasat, 2002; Kumar \& Benbasat, 2002) - which relates to the distance between the customer and the company; and

- $\quad$ product perception (Jiang \& Benbasat, 2002; Jarvenpaa \& Todd, 1997) which refers to the distance between the customer and the product.

While both these issues are clearly important in any overall discussion of relationship management, this paper focuses on product perception.

Although there has been much excitement over the potential of "interactivity" on the Internet, very little is understood about exactly what creates a sense of presence or interactivity, and what impact this has on user behaviour. Businesses are spending millions of dollars to add games, animation and personalisation tools to their web sites without really knowing what effect this has on their customers (Klein, 2001). 
Essentially, the question to be resolved is what is meant by "presence" in a web environment. Despite the popularity and academic interest in this topic, the centrality and importance of presence has not yet been studied in much depth. Lombard and Ditton (1997) noted that the work which had thus far been done was fragmentary and unsystematic, partly because the people interested in presence came from many different academic backgrounds. They added that the more specific, focused research conducted by private industry and government had mostly remained proprietary.

Media alternatives can vary widely in terms of the quality and quantity of the product information they can transmit to consumers, compared with what is generally considered the consumer's best source of product information - direct product experience (Klein 2001). The traditional electronic media, such as radio and television, are unable to deliver customised product information, but the Internet has the potential to deliver product information in both personally-customised and realistic ways, so that the receiver may interpret the information much more as though it came from their own direct experience than they can with advertising from traditional media sources (Klein, 2001; Hou and Rego, 2002).

In recent years, the improvement of eCommerce interface design has led to easier navigation, more attractive graphic interfaces and more powerful plug-in components (Jiang \& Benbasat, 2002; Lohse \& Spiller, 1997; Gehrke \& Turban, 1999; Kim \& Yoo, 2000; Nielsen, 1999), although researchers are still doubtful about the effectiveness of online shopping (Jiang \& Benbasat, 2002; Wolfinbarger \& Gilly, 2001; Rose et al., 1999; Bhatnagar et al., 2000). The argument is that the web interface is constrained, since online consumers can only passively receive the product information presented, without being able to feel, touch, or try online products, which significantly limits their perception of the products they purchase in this way (Jiang \& Benbasat, 2002).

To address this issue, a variety of forms of improved product presentation have been suggested. For instance, online consumers are currently able to simulate direct product experience (Jiang \& Benbasat, 2002; Kempf \& Smith, 1998) either by means of 3D or Virtual Reality (Jiang \& Benbasat, 2002; Li et al., 2000; 2002a; 2002b; Peek, 1997). Virtual reality or virtual product experience allows the consumer to interact with online products and experience a much wider range of those products' features (Jiang \& Benbasat, 2002; Ryan, 2001). Earlier exploratory studies have suggested that virtual reality has the potential to improve the consumers' product knowledge and brand attitude, including enhancing their purchase intentions (Jiang \& Benbasat, 2002; Li et al., 2002, 2002a, 2002b; Daugherty et al., 2002).

The use of virtual product models can be extended to product development, customisation, marketing, manufacturing, and selling of products for Internet based virtual companies (Pulli, Antoniac \& Hickey, 1999). As we noted earlier, however, both Knudsen (2002) and Enlund (2000) recommend that the producers of virtual reality continue to concentrate on the technical skills upon which the improved sensory user-environment must be based, as well as on learning how to produce quality content which will support the creation of a strong sense of presence and reality. Kim \& Biocca (1997) point out that when users feel "present" in a virtual environment, they are also more likely to be persuaded to purchase or use the product being sold.

Virtual prototyping models offer an entirely new perspective for eCommerce on the Internet as they provide a strong sense of reality through meaningful interaction, which allows the model of a product to be tested. This is because all-digital prototypes resemble their physical counterparts as closely as possible with visual three-dimensional images, 
behavioural, haptic and auditory characteristics. Online trial of products can also be offered where customers can browse in a virtual salesroom to test operations of a virtual prototype, simulated to mimic its physical counterpart (Pulli, Antoniac \& Hickey, 1999). Of course, the success of such approaches depends, to a large extent, on how convincing the user's experience with the virtual prototype is. How "realistic" is virtual reality today?

\section{THE "EXPERIENCE ECONOMY"}

Pine and Gilmore (1999), in their seminal work which first brought the concept of the "Experience Economy" to public notice, observe that price competition is no longer sufficient to sustain growth and profitability - and conclude that companies must find new ways of adding value to their business. In its simplest sense, the concept can be described by saying that consumers are now buying experiences as well as goods and services. Voss $(2003, p 4)$, in a report of a major piece of empirical work which identifies some of the key management and business trends in experience, states that: "creating outstanding and memorable experiences has become central ... to an increasing number of businesses, as companies seek to build the emotional involvement that goes with them".

Pine and Gilmore believe that experiences are a fourth economic offering, following on from commodities, goods and services (see Figure 1). Each successive offering greatly increases in value, because the buyer finds each more relevant to what $\mathrm{s} / \mathrm{he}$ truly wants. And because companies stage so many different kinds of experiences, they can more easily differentiate their offerings and hence charge a premium price based on the distinctive value provided. Pine and Gilmore add that businesses need a strategy for managing these four dimensions of value creation.

Voss (2003) points out that experiences create "emotional responses and connections with products and brands which are difficult to build in any other way", adding that one of the opportunities thus provided is the chance to try out products, which allows the shopper to build a form of involvement with the product. Pine and Gilmore believe that experiences have always existed, but that consumers, businesses and economists previously lumped them into the service sector along with such unexciting activities as dry cleaning, auto repair, telephone access or wholesale distribution.

Pine and Gilmore point out that when customers buy a service, they purchase a set of intangible activities carried out on their behalf. But when they buy an experience, they pay to spend time enjoying a series of memorable events staged by the company - as in a theatrical play - which engage them in a personal way. 


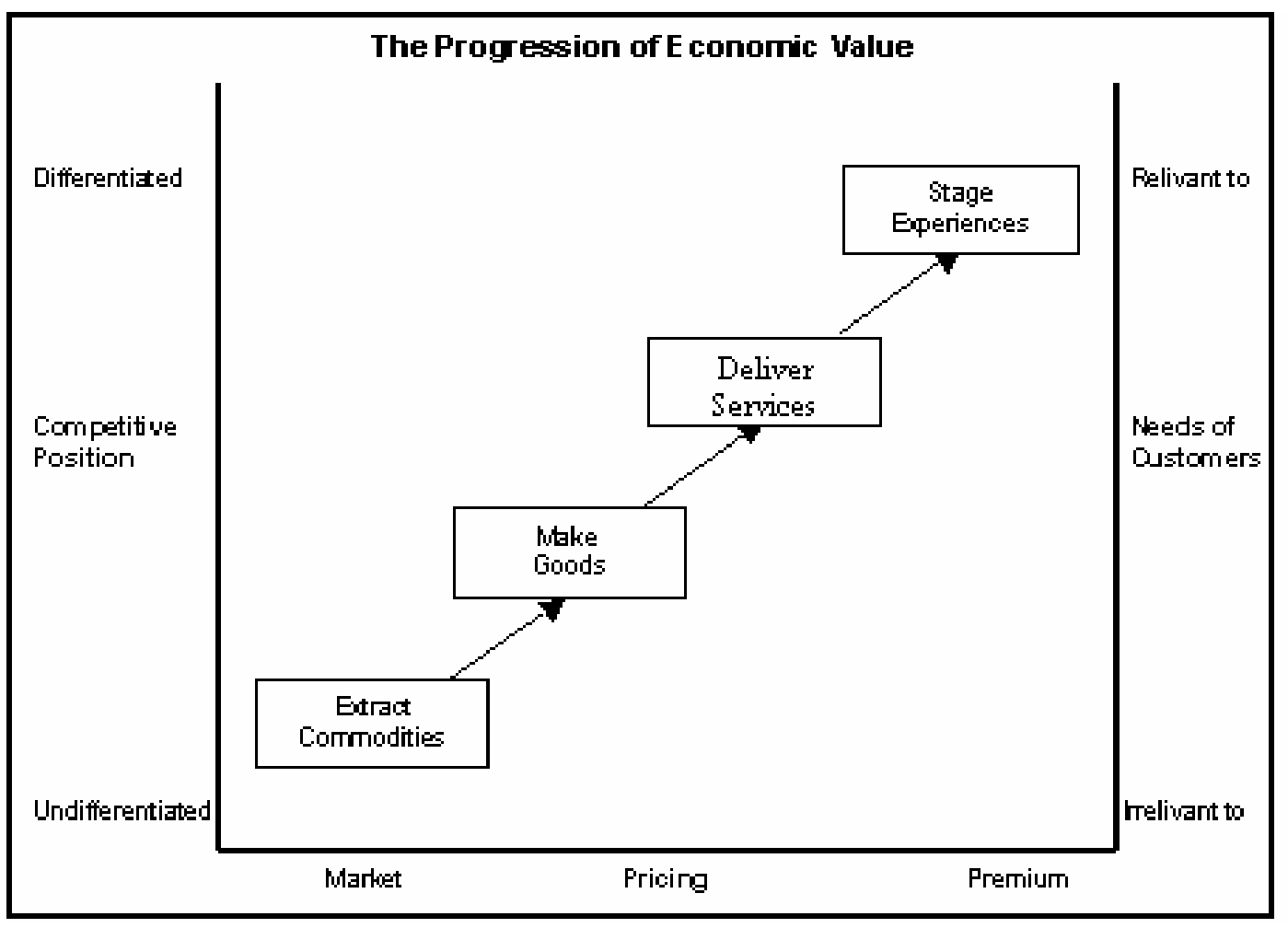

Figure 1. The progression of economic value (Pine \& Gilmore, 1999, p.22)

The answer provided by the Experience Economy thus lies partly in technology, which powers so many experiences, and partly in the increasingly competitive intensity which drives the ongoing search for differentiation. Bruns (2002) suggests that the Experience Economy not only offers practical insights into how business can respond more effectively to the reshaping of demand, but also provides a framework for thinking about how advanced technologies can be used in the online environment to enhance experience. These authors all highlight the need to engage online shoppers with a memorable shopping experience, rather than simply selling goods and services on the Internet. The question which naturally emerges is just how that memorable experience is to be obtained by the online shopper. In the following sections, we discuss the possibility that Virtual Reality may be able to offer at least a partial solution to the problem of making online shopping into a pleasant and memorable experience.

\section{DIRECT PRODUCT EXPERIENCE}

Direct Product experience (also known as product trial), describes a consumer's direct feel, touch and trial of a product. It is generally believed to be one of the most effective, yet most costly, ways to introduce a new product (Jiang \& Benbasat, 2002; Kotler, 1988).

There are several reasons why product trial should be taken seriously by researchers interested in online retailing success factors (Jiang \& Benbasat, 2002; Kempf \& Smith, 1998; Hoch \& Deighton, 1989). Firstly, direct experience involves multiple sensory cues, such as vision, feel, smell, taste and sound. When combined together, these cues form a 
vivid, informative and impressive presentation of products. Secondly, as consumers are involved in the direct experience, they will be more motivated to evaluate products and their attention and engagement should be more aroused (Jiang \& Benbasat, 2002). In addition, as all product information is generated by the consumers themselves during product trial, it possesses greater credibility and trustworthiness than information supplied by manufacturers or retailers.

Learning from direct experience is a self-controlled experience and consumers can thus control the way they receive, store, and process product information, leading to more effective management of product information (Jiang \& Benbasat, 2002). Studies undertaken by Smith and Swinyard $(1983 ; 1988)$ found that belief and attitude confidence was significantly higher when consumers were exposed to product sampling only, than when exposed to advertising only; while Marks \& Kamins (1988) also found that attitude formed through direct product experience was held more confidently and was less susceptible to change than advertising.

Other research (Jiang \& Benbasat, 2002) has suggested that the effect of direct product experiences is dependent on product attribute categories. Nelson (1974) had previously identified these as:

- $\quad$ search attributes: those whose information are conveyed better through second-hand sources, such as catalogues, advertising or word-of-mouth, than direct trial of products; and

- $\quad$ experience attributes (with an obvious, though in this domain of research unstated, link to the work of Pine \& Gilbert (1999), Voss (2003) and others).

Making use of this categorisation, Wright and Lynch (1995) found that direct product experience led to higher belief confidence and accessibility of experience attributes than advertising, while advertising resulted in higher belief confidence and accessibility of search attributes.

A growing number of researchers are now investigating the impact of $3 \mathrm{D}$ virtual product experience as a substitute for direct product experience, especially in relation to the influence of virtual advertisements (see, for example, Daugherty et al., 2001; 2002; Jiang \& Benbasat, 2002; Li et al., 2001; 2002a; 2002b: Peck \& Childers, 2003).

The major questions which remain, therefore, are firstly how attractive online shopping is overall, whether online consumers are willing to experiment with virtual presentation of their shopping experience and, most importantly, whether this experience is sufficiently rich to provide a substitute for the "real" world.

\section{UNDERSTANDING ONLINE SHOPPING BEHAVIOUR}

Despite all the hype surrounding Internet shopping, a large proportion of online shoppers still do not purchase online (CGEY, 2000). This Cap Gemini/Ernst \& Young survey of Canadian online shoppers found that the top five barriers to purchasing online goods or services were: (i) security concerns $(22 \%)$, (ii) too impersonal $(20 \%)$, (iii) time consuming/frustrating (13\%), (iv) difficulty navigating sites (11\%), and (v) not enough or too much information (10\%) (CGEY, 2000).

A number of commercial studies have suggested that online shopping is simply not taking off as predicted. For example, Van Putten (2000) cites a Forrester Research study which found that $40 \%-60 \%$ of intended online purchases were abandoned once shoppers reached 
the check-out page; and a major study of 12,000 US consumers by the Boston Group (2000) found that $28 \%$ of attempted online purchases failed, and four out of five consumers purchasing online had experienced at least one failed purchase attempt. And this problem is still with us - Elgin (2003) found that Google's new shopping service, Froogle, was not showing the rapid growth its highly successful parent had expected and hoped for.

Why is online shopping growing so much more slowly than forecast, long after the dot.com crash? Does the answer lie in the experience consumers seek when they shop online and the limited ability of today's online shopping environments to fulfil those needs and wants? Smith (2003) explains that understanding motivations is crucial when considering why people shop online, believing that we need an understanding of people's basic motivations for shopping in general as well as, more specifically, the motivators for collecting information and shopping on the Internet. He wonders why we make purchases - and asks whether all shopping activities are motivated by the same behaviour.

Tauber (1972) identified a variety of personal and social motives for shopping behaviour (see Table 3). These motives are often disguised, or perhaps are even unknown to the shopper him/herself - but they have an effect on the times we choose to shop, the stores we choose to enter, and the brands of products and services we choose to purchase.

\begin{tabular}{|l|l|}
\hline Personal Motives for Shopping & Social Motives for Shopping \\
\hline Role playing & Social experience \\
\hline Recreation & Communication with others \\
\hline Self gratification & Peer group attraction \\
\hline Learning about new trends & Status and authority \\
\hline Sensory stimulation & The pleasure of bargaining \\
\hline
\end{tabular}

Table 3. A summary of Tauber's (1972) personal and social shopping motives

These motives are likely to be as relevant to online shopping as to "traditional" shopping activities. Hoffman et al. (2003) noted that many of the well-known B2C retail failures had been attempting to replicate offline shopping patterns online, while success stories often included those eTailers taking advantage of 'Webby' applications such as MP3 file sharing (peer-to-peer exchanges), instant messaging, or C2C models. This finding is similar to that of Albers et al. (2002), whose study of 10 successful online B2C companies indicated that profitable companies in this sector developed Internet-oriented business models right from the start - offering digitalised products and significant added-value for consumers, rather than replicating offline business models.

But before we write-off the idea of selling conventional products online completely, it is worth considering other possible influences affecting online retailing:

- Age-related online consumption behaviour suggests that when "younger surfers who have grown up on the net become full-fledged consumers, experiential benefits are likely to become more desirable" (Wolfinbarger \& Gilly, 2001, p.52). Peck \& Childers (2003) identified the high 'need-for-touch' (NFT) group, who were more likely to purchase products they could touch - either physically, or by using haptic touchsubstitutes.

- The online interface relates to the way in which firms such as Amazon and Autobytel have managed to expand globally by creating a standardised, transaction-oriented interface, so that users always know what to expect (Cole \& O'Keefe 2000). Since these pure-play online 
retailers primarily focus on the sale of 'traditional' physical goods, it would appear that their interface is generally successful - whether individual shoppers like it or not.

A number of researchers have begun to investigate the impact which the web site's user interface has on retail success:

- Lohse \& Spiller (1998; 1999) and Spiller \& Lohse (1998) confirmed a strong link between a web site's B2C interface and the volume of traffic and, more importantly, sales achieved by the site;

- Eroglu, Machleit \& Davis (2001) found that web site 'stickiness' was influenced by the virtual store's atmosphere;

- Wolfinbarger \& Gilly (2003) found that the four issues of website design, product fulfilment \& reliability, web site privacy \& security awareness, and customer service all have a strong positive link with the customer's belief in the quality of the retail site; and with their satisfaction, loyalty and overall attitude toward the etailer; and

- Peck and Childers (2003) research into the addition of haptic features to enhance the shopping experience suggest that visual cues alone are not sufficient for long-term success in cyber-shopping experiences.

In discussing the role of 'affect' in human-computer interaction, Hudlicka (2003) notes that: "in some research communities we no longer even speak of users and machines as separate entities, but rather of collaborative systems, integrated human-machine systems and joint cognitive systems" (p.2). She makes the very relevant point that online agents capable of interacting with humans in a seamless and adaptive manner will need to be able to recognise and respond to user affect. This, it seems to us, sums up the discussion about the most effective environment for online shopping rather neatly - only when online shoppers are positively affected by their virtual shopping experience will they turn their backs on 'traditional' retail environments and flock to the internet in huge numbers.

\section{VIRTUAL PRESENCE IN RETAILING TODAY}

The range of virtual reality-enhanced online shopping venues today is still comparatively limited, although a number of experiments in applying virtual reality to online shopping have already been attempted. Indeed, this may be part of the problem - highly publicised failures, like that of Boo.com (the online apparel retailer discussed below), have made many people wary of using sophisticated technologies like virtual reality to enhance online fashion retailing or, indeed, any form of online retailing.

Although the examples currently available are still limited, there is much to be learned from what is being achieved and from the way in which it is implemented - and perhaps even more to be learned from the failures. The following dot-points briefly describe two examples of online virtual presence: a spectacular failure, and a less well-known software solution being used by a number of fashion etailers to enhance the buying experience for their customers with considerable success:

- Boo.com - presented itself as a cool online fashion retailer which understood the needs of its young customers and could offer them not only the world's largest online catalogue of fashion images (fully rotational and impressively VR-enhanced), but also the ability to "try" 
apparel items on personal electronic avatars; a sophisticated virtual shopping assistant to guide purchases; and links between purchasing history and new product arrivals. After a two-year development period, the site belatedly went live in November 1999 and, despite its many technical problems, was rated highly by the media and its customers (Stockport, Kunnath and Seddick, 2001). However the strain of producing integrated systems ultimately proved too taxing. The launch date slipped further and further and, when the site did go live, it was still not really ready - too slow, too complicated and far too prone to error (Stockport, 2000). Boo.com closed its virtual doors only six months after first opening them.

- My Virtual Model - A more modest, but considerably more successful, approach to VR-assisted fashion etailing is My Virtual Model ${ }^{\mathrm{TM}}$ (MVM), which was initially released in 1997. More than three million models have since been created using MVM software and the company's web site claims that shoppers using these solutions spend more, buy more and return far fewer items - resulting directly in reduced shipping and handling costs (ITAC, 2001). Once a would-be shopper has created and registered his/her model, it can be re-used on the web sites of other MVM etailers. Lands' End, the best-known MVM user, says that the software has enabled the company to gain a better understanding of purchasers' preferences and intentions, since these are automatically stored in a demographic database and can be re-used by other applications, including planning and procurement (Edwards, 2000). The modest, but very real, success of My Virtual Model ${ }^{\mathrm{TM}}$ at all adopting web sites suggests that online shoppers are ready for a more interesting and exciting experience than they are currently able to obtain.

\section{CONCLUSION}

Online shopping is likely to be driven by the same (or similar) motives as is face-to-face shopping. Beyond its obvious benefit in terms of convenience ${ }^{21}$, online shopping must satisfy the personal and social goals identified by Tauber (1972) and Westbrook \& Black (1985) - it must, in the words of Pine \& Gilmore (1999) offer an 'experience' sufficiently desirable to warrant its use. Virtual reality has the potential to make shopping just such an experience - not merely in terms of providing a virtual substitute for the human shop assistant, but also in terms of its ability to recognise and provide what each individual users seeks from his/her shopping. Just how far that experience should go is something which will be limited by technology and by the user's willingness to immerse him/herself in the experience.

Users are becoming increasingly sophisticated in their expectations of computer technology and Hudlicka (2003) points out that this growing sophistication, combined with escalating technical progress, is leading to a redefinition of what is understood by effective and desirable human-computer interaction. In other words, Miss Boo may have been ahead of

${ }^{21}$ This paper does not touch upon the potential benefits of online shopping for those temporarily or permanently unable to go shopping physically, although this is clearly a matter of no small importance to those affected. 
her time, technically speaking, but it will probably not be long before such virtual assistants become relatively commonplace in $\mathrm{B} 2 \mathrm{C}$ etailing.

How much further immersion needs to go is still unclear. Peck \& Childers (2003) believe that without haptic extensions, many forms of online shopping are unlikely to be truly successful. They suggest that while those shoppers whose sense of touch is not strongly developed (low-NFT shoppers, whose motivation and/or ability to obtain haptic information is minimal) may not require such enhancements, while high-NFT shoppers "may be difficult to convert to users of non-touch media" (p.48).

In this paper we have explored the elements of virtual presence and online shopping, seeking to find a way to replicate the essential shopping experience in a virtual environment. Voss's (2003) wide-ranging study of the Experience Economy found that successful companies across many sectors created "outstanding and memorable experiences" for their customers and users. The limited, but encouraging, success of My Virtual Model for apparel stores across the USA and Europe suggests that, even in its present state, a virtual avatar offers a real advantage to those engaged in the very challenging task of selling clothing online. And apparel is by no means the only industry to make this discovery - car manufacturers and dealers have also been investing in 3D technology to help them break into the tough, but potentially lucrative, online automotive market. Mercedes has been using VR for nearly four years to offer would-be buyers of its innovative Geländerwagen SUVs (www.gwagen.com) a virtual test drive (Edwards, 2000). The California start-up Realitybuy.com (www.realitybuy.com), beginning with the B2B market, has now successfully created cheap, readily-created virtual objects for B2C furniture and office suppliers, motor-bike dealers, computer manufacturers and jewellery stores (to name only a few of their applications).

Online consumers are finding the virtual shopping experience more and more effective. Virtual reality alone is not yet sufficiently technically advanced to create a true sense of presence, of "being there". But the addition of such features as simulations which show just what the product could do; recommender systems which show what other buyers have liked; and chat rooms which provide the opportunity to discuss the product with both the sellers themselves and with other buyers go a long way towards creating a memorable experience which will persuade online shoppers to buy. This literature-based study as yet just hints at the likely uses of VR for eTailing -the next stages of this research project will involve the gathering and analysis of empirical data and will provide a solid foundation for predictions of what awaits online shoppers over the next few years.

\section{REFERENCES}

Albers, S., Panten, G. and Schäfers, B. (2002). Die eCommerce-Gewinner: Wie Unternehmen im Web profitabel wurden. 10 Erfolgsgeschichten aus erster Hand, F.A.Z.-Institut, Frankfurt, URL:

http://www.faz-institut.de/IN/INtemplates/FAZinst/doc.asp?doc $=\{$ D3DA315F-A41347FA-85A1-614AF0BF2AF7 $\} \&$ rub $=\{9 A 874892-B 40 D-4 E E D-B 5 B F-5781 D 1129973\}$, [Last Accessed: 23/08/2003].

Benbasat, I. \& DeSanctis, G. (2000). “Communication Challenges: A Value Network Perspective", In G. Dickson and G. DeSantis (Eds.): Information Technology and the Future Enterprise: New Models for Managers. Prentice-Hall, Englewood Cliffs, NJ.

Bhatnagar, A., Misra, S. and Rao, H.R. (2000). "On Risk, convenience, and Internet Shopping Behaviour", Communications of the ACM, Vol 43 No. 11, pp98-105. 
Biocca, F., \& Levy, M. R. (1995). Communication in the age of virtual reality, Lawrence Erlbaum Associates, Hillsdale, NJ.

Boston Group (2000). "Winning the Online Consumer: insights into online consumer behaviour", Boston Consulting Group Research Report, URL:

http://www.bcg.com/publications/files/Winning_Online_Consumer_Insights_Rep ort Mar00.pdf [Last Accessed: 21/08/2003]

Bruns, B. (2001). "NanoTechnology and the Experience Economy", Nanodot:

http://nanodot.org/article.pl?sid=01/02/10/063220 [Last accessed 22/5/03]

CGEY (2000). "Canadians Kick Tires Online - But Few Complete the Deal". URL:

www.ca.cgey.com/news/press_releases/pr_march21_00.htm [Last accessed 22/5/03]

Cole, M. and O'Keefe, R.M. (2000). "Conceptualising the dynamics of globalisation and culture in electronic commerce", Journal of Global Information Technology Management, Vol. 3, pp4-17.

Daugherty, T., Li, H. and Biocca, F. (2002). "Experiential Ecommerce: A Summary of Research Investigating the Impact of Virtual Experience on Consumers Learning”, In C. Haugtvedt, K. Machleit and R. Yalch (Eds) (2002) Online Consumer Psychology: Understanding Influencing Consumer Behaviour in the Virtual World, Lawrence Erlbaum Associates.

Dennis C., Patel, T., King, T., and Hilton, J. (2002). “Qualitative Studies of Shoppers' Motivations", $9^{\text {th }}$ International Conference on Recent Advances in Retailing and Services Science, EIRASS, Heidelberg, Germany, August, URL:

http://dallas.brunel.ac.uk/modres_uploads/BS3416S/QualMotivation.doc

[Last Accessed: 11/08/2003]

Edwards, J. (2000). "3-D finally gets serious", CIO.com.Magazine, March 1, URL:

http://www.cio.com/archive/030100/et.html [Last Accessed: 23/08/2003]

Elgin, B. (2003). “Google's Offspring: taking baby steps”, Business Week Online, March 19, URL: http://www.businessweek.com/technology/content/mar2003/tc20030319 7982 tc016.ht m, [Last Accessed: 21/08/2003].

Enlund, N. (2000). "The Production of Presence - Distance techniques in Education", Publishing and Art, ACS'2000 Proceedings, Szczecin.

Eroglu, S.A., Machleit, A.K. and David, L.M. (2001). „Atmospheric qualities of online retailing: a conceptual model and implications", Journal of Business Research, Vol. 54, Issue 2, Nov., pp177-184.

Gehrke, D. and Turban, E.(1999). "Determinants of Successful Website Design: Relative Importance and Recommendations for Effectiveness", Proceedings of the $32^{\text {nd }}$ Hawaii International Conference on System Sciences.

Hoch, S.J. \& Deighton, J. (1989). Managing What Consumers Learn from Experience, Journal of Marketing, Vol. 53, Iss.2; pp1-20.

Hoffman, D.L., Novak, T.P. and Duhachek, A. (2003). "The Influence of Goal-Directed and Experiential Activities on Online Flow Experiences", Journal of Consumer Psychology - Special Issue on "Consumers in Cyberspace", Vol. 13, Nos. 1\&2, pp317.

Hou J. and Rego C. (2002). "Internet Marketing: an Overview”, Working Paper University of Mississippi, URL: http://faculty.bus.olemiss.edu/crego/papers/hces0802.pdf [Last accessed 11/08/03].

Hudlicka, E. (2003). "To feel or not to feel: the role of affect in human-computer interaction", International Journal of Human-Computer Studies, Vol. 59, pp1-32. 
IJsselsteijn, W. (2002). "Elements of a multi-level theory of presence: phenomenology", mental processing and neural correlates, PRESENCE 2002 - 5th International Workshop on Presence, Porto, Portugal, 9-11 October, 245-259.

ITAC (2001). "Electronic Commerce in Canada Success Stories: My Virtual Model Inc"., Electronic Commerce Task Force of the Information Technology Association of Canada, URL: http://i-com.ic.gc.ca/english/ stories/mvmsucc.html [Last Accessed: 31/08/2003].

Jarvenpaa, S.L. and Todd, P.A (1996). "Consumer Reactions to Electronic Shopping on the World Wide Web”, International Journal of Electronic Commerce, Winter 1996-97, Vol. 1, No. 2, pp 59-88.

Jiang, Z. \& Benbasat, I. (2002). "Virtual Product Experience: Effects of Visual \& Functionality Control of Products on Perceived Diagnosticity in Electronic Shopping", University of British Columbia.

Kempf, D.S. \& Smith, R.E. (1998). "Consumer Processing of Product Trial and the Influence of Prior Advertising: A Structural Modelling Approach", Journal of Marketing Research, Vol. XXXV, pp.325-337.

Kim, T. and Biocca, F. (1997). "Telepresence via Television: Two Dimensions of Telepresence May Have Different Connections to Memory and Persuasion:”, Journal of Computer-Mediated Communication, Vol. 3, No. 2, September, URL:

www.ascusc.org/jcmc/vol3/issue2/kim.html\#Factor [Last accessed 14/08/2003]

Kim, J. and Yoo, B. (2000). "Toward the Optimal Link Structure of the Cyber Shopping Mall”, International Journal of Human-Computer Studies, Vol. 52, pp 531-551.

Klein, L.R. (2001), Creating "Virtual Experiences in Computer-Mediated Environments", Rice University

http://www.bepress.com/cgi/viewcontent.cgi?article=1001\&context=roms [Last accessed $22 / 5 / 03]$

Knudsen, C.J. (2002). "Video Mediated Communication”, Royal Institute of Technology, Sweden.

http://kmr.nada.kth.se/papers/TelePresence/VMC_Knudsen_Banff_2002.pdf [Last accessed 22/5/03]

Kotler, P. (1998). Marketing Management, Prenctice-Hall, Englewood Cliffs, NJ.

Kumar, N. and Benbasat, I. (2002). "Para-social Presence: A Re-conceptualization of "Social Presence" to capture the Emerging Relationship between a Web Site and Her Visitors", Proceedings of the $35^{\text {th }}$ Annual Hawaii International Conference on System Sciences (HICSS), Hawaii.

Lessiter, J., Freeman, J., Keogh, E. and Davidoff J. (2000) "Development of a New CrossMedia Presence Questionnaire: The ITC-Sense of Presence Inventory”, PRESENCE 3rd International Workshop on Presence, Technical University of Delft, Delft, Netherlands, March 27-28.

Li, H., Daugherty, T. and Biocca, F. (2001). "Characteristics of Virtual Experience in Electronic Commerce: a Protocol Analysis", Journal of Interactive Marketing, Vol. 15, No. 3, Summer, pp13-30.

Li, H.; Daugherty, T. and Biocca, T. (2002a). "The Role of Virtual Experience in Consumer Learning", Journal of Consumer Psychology.

Li, H. Daugherty, T. and Biocca, T. (2002b). "Impact of 3D Advertising on Product Knowledge, Brand Attitude, and Purchase Intention: the Mediating Role of Presence", Journal of Advertising, Vol. 31, No. 3, pp 43-57.

Lohse, G. L. and Spiller, P. (1998). "Electronic Shopping: how do customer interfaces 
produce sales on the internet", Communications of the ACM, Vol. 41, No. 7, pp81-87.

Lohse, G.L. and Spiller, P. (1999). "Internet Retail Store Design: how the user interface influences traffic and sales", Journal of Computer-Mediated Communication, Vol. 5, No. 2, Available online URL:

http://www.ascucs.org/jcmc/vol5/issue2/lohse.htm [Last Accessed: 22/08/2003].

Lombard, M. and Ditton, T. (1997). "At the Heart of It All: The Concept of Presence", Temple University. URL:

www.ascusc.org/jcmc/vol3/issue2/lombard.html\#Abstract [Last accessed 15/3/03]

Marks, L.J. \& Kamins, M.A. (1988). "The Use of Product Sampling and Advertising: Effects of Sequence of Exposure and Degree of Advertising Claim Exaggeration on consumers' Belief Strength, Belief Confidence, and Attitudes", Journal of Marketing Research, Vol. XXV, August, pp. 266-281.

Nelson, P. (1974). “Advertising as Information”, Journal of Political Economy, 83, July/August.

Nielsen, J. (1999). Designing Web Usability: The Practice of Simplicity, New Riders Publishing, December.

Peck, J. and Childers, T.L. (2003). "To have and to hold: the influence of haptic information on product judgments", Journal of Marketing, Vol. 67, No. 2, pp35-56.

Peek, R. (1997). "Is the Web Ready for 3D? Should you Be?", Information Today, Medford, Dec, Vol. 14, Issue 11.

Pine II, J.B. \& Gilmore, J. H. (1999). The Experience Economy - Work is Theatre and Every Business a Stage, Harvard Business School Press, Boston, USA.

Pulli, P.; Antoniac, P. \& Hickey, S. (1999). "Mobile Telepresence Services for Virtual Enterprise". URL:

http://paula.oulu.fi/Publications/Submited/ICE99.pdf [Last accessed 22/5/03]

Rose, G., Khoo, H. and Straub, D.W. (1999). "Current Technological Impediments To Business-To-Consumer Electronic Commerce", Communications of the Association for Information systems, Vol. 1, Article 16, June.

Ryan, C. (2001). "Virtual Reality in Marketing”, Direct Marketing, Vol. 63, Issue 12, April.

Schiffman, L., Dash, J. and Dillon, W. (1977). "The Contribution of Store Image Characteristics to Store-Type Choice”, Journal of Retailing, Vol. 53, Summer.

Schubert, T., Friedmann, F. and Regenbrecht, H. (1999) "Embodied Presence in Virtual Environments", In Ray Paton \& Irene Neilson (Eds.) (1999) Visual Representations and Interpretations, pp. 268-278. London: Springer-Verlag.

Smith S.M. (2003). "Internet Marketing: an online text", URL:

http://marketing.byu.edu/htmlpages/courses/490r/chapters/text.html [Last Accessed: $14 / 08 / 2003]$

Smith, R.E. \& Swinyard, W.R., (1988). "Cognitive Response to Advertising and Trial: Belief Strength, Belief Confidence and Product Curiosity", Journal of Advertising, Vol 17, No.3, 1988, pp3-14.

Spiller, P. and Lohse, G.L. (1998). "A classification of internet retail stores”, International Journal of Electronic Commerce, Vol. 2, No. 2, pp29-56.

Steuer, J.S. (1992). "Defining virtual reality: Dimensions determining telepresence", Journal of Communication, Vol. 42, No. 4, pp73-93.

Stockport, G.J. (2000). Boo.com - the path to Failure, European Case Clearing House, Case 300-168-1.

Stockport, G.J., Kunnath, G. And Sedick, R. (2001). "Boo.com - the path to Failure”, 
Journal of Interactive Marketing, Vol. 15, No. 4, pp56-70.

Tauber E.M. (1972). "Marketing Notes and communications: why do people shop?", Journal of Marketing, Vol. 36, October, pp46-59.

Van Putten, C. (2000). "The Top 5 Barriers to Smooth Online Shopping”, Flash Commerce News, URL: http://flashcommerce.com/articles/00/03/03/120430320.htm [Last Accessed: 21/08/2003]

Voss C. (2003). The Experience Profit Cycle: trends in the experience and service economy, Research Report, London Business School, July, p4.

Westbrook R.A. and Black W.C. (1985). "A motivation-based shopper typology”, Journal of Retailing, Vol. 61, No. 1, pp78-103.

Wolfinbarger, M. and Gilly, M.C., (2001). "Shopping Online for Freedom, Control and Fun”, California Management Review, Vol. 43, No. 2, Winter; pp34-55.

Wolfinbarger, M. and Gilly, M.C., (2003). "eTailQ: dimensionalizing, measuring and predicting etail quality”, Journal of Retailing, Vol. 79, No. 3, Fall, pp183-198.

Wright, A.A. and Lynch, Jr., J.G., (1995), "Communications Effects of advertising versus Direct Experience when both Search and Experience Attributes are Present", Journal of Consumer Research, Vol. 21, March, pp708-718. 